\title{
S100A6 wt Allele
}

National Cancer Institute

\section{Source}

National Cancer Institute. S100A6 wt Allele. NCI Thesaurus. Code C99606.

Human S100A6 wild-type allele is located in the vicinity of $1 \mathrm{q} 21$ and is approximately $2 \mathrm{~kb}$ in length. This allele, which encodes protein S100-A6, plays a role in both signaling and calcium binding. 